\title{
SCIENTIFIC REP RTS OPEN Publisher Correction: Biodiversity conservation gaps in the Brazilian protected areas
}

Ubirajara Oliveira ${ }^{1,2}$, Britaldo Silveira Soares-Filho ${ }^{1}$, Adriano Pereira Paglia ${ }^{3}$, Antonio D. 
Brasileira (http://www.hympar.ufscar.br/). CJB de Carvalho (CNPq 304713/2011-2), AD Brescovit (CNPq 303028/2014-9; FAPESP 2011/50689-0), Data acquisition on stingless bee specimens at the American Museum of Natural History by JSA occurred with help the from HH Go, A Pfister, M Tuell and ES Wyman. It was supported by RG Goelet and by a NSF-DBI grant (\#0956388 with JS Ascher as the P.I., and JG Rozen Jr. and D Yanega as co-P.I.s). DPS received a research productivity grant from Federal Goiano Institute (Bolsa PAPPE process number 23216.000573/2017-61)."

(c) (i) Open Access This article is licensed under a Creative Commons Attribution 4.0 International License, which permits use, sharing, adaptation, distribution and reproduction in any medium or format, as long as you give appropriate credit to the original author(s) and the source, provide a link to the Creative Commons license, and indicate if changes were made. The images or other third party material in this article are included in the article's Creative Commons license, unless indicated otherwise in a credit line to the material. If material is not included in the article's Creative Commons license and your intended use is not permitted by statutory regulation or exceeds the permitted use, you will need to obtain permission directly from the copyright holder. To view a copy of this license, visit http://creativecommons.org/licenses/by/4.0/.

(C) The Author(s) 2018 